\title{
Article \\ Metal Bioaccumulation by Carp and Catfish Cultured in Lake Chapala, and Weekly Intake Assessment
}

\author{
Claudia Alvarado ${ }^{1, * \mathbb{D}}$, Diego M. Cortez-Valladolid ${ }^{1}$, Enrique J. Herrera-López ${ }^{2}{ }^{\mathbb{D}}$, Ximena Godínez ${ }^{1}$ \\ and José Martín Ramírez ${ }^{3}$ \\ 1 Centre for Research and Assistance in Technology and Design of Jalisco State A.C., Food Technology Unit, \\ Camino Arenero 1227, El Bajío del Arenal, Zapopan 45019, Jalisco, Mexico; \\ d.cortez.v@outlook.com (D.M.C.-V.); x1m3n.n@gmail.com (X.G.) \\ 2 Centre for Research and Assistance in Technology and Design of Jalisco State A.C., Industrial Biotechnology, \\ Bioelectronics LINBIA Laboratory, Camino Arenero 1227, El Bajío del Arenal, Zapopan 45019, Jalisco, Mexico; \\ eherrera@ciatej.mx \\ 3 Centre for Research and Assistance in Technology and Design of Jalisco State A.C., Analytic and Metrologic \\ Services Unit, Av. Normalistas 800, Colinas de la Normal, Guadalajara 44270, Jalisco, Mexico; \\ mramirez@ciatej.mx \\ * Correspondence: calvarado@ciatej.mx; Tel.: +52-(33)-3345-5200 (ext. 2130)
}

check for updates

Citation: Alvarado, C.;

Cortez-Valladolid, D.M.;

Herrera-López, E.J.; Godínez, X.;

Ramírez, J.M. Metal Bioaccumulation

by Carp and Catfish Cultured in Lake

Chapala, and Weekly Intake

Assessment. Appl. Sci. 2021, 11, 6087.

https://doi.org/10.3390/

app11136087

Academic Editor: Elida Nora Ferri

Received: 28 April 2021

Accepted: 23 June 2021

Published: 30 June 2021

Publisher's Note: MDPI stays neutral with regard to jurisdictional claims in published maps and institutional affiliations.

Copyright: (c) 2021 by the authors. Licensee MDPI, Basel, Switzerland. This article is an open access article distributed under the terms and conditions of the Creative Commons Attribution (CC BY) license (https:// creativecommons.org/licenses/by/ $4.0 /)$.

\begin{abstract}
Aquaculture offers great potential for fish production in Lake Chapala, but reports of heavy metal contamination in fish have identified a main concern for this activity. In the present study, cultures of the species Cyprinus carpio and Ictalurus punctatus were grown in a net cage in Lake Chapala. The patterns of heavy metal accumulation $(\mathrm{Cu}, \mathrm{Zn}, \mathrm{Cd}, \mathrm{Hg}, \mathrm{Pb}, \mathrm{As})$ in muscle and liver were monitored in order to evaluate the level of metal incorporation in the fish. Estimates of weekly metal intake (EWI) were made based on the results of the concentrations in edible parts of fish of commercial size. The patterns of metal bioaccumulation between tissues and species showed that liver had a higher concentrating capacity for $\mathrm{Zn}, \mathrm{Cu}, \mathrm{Cd}$, and $\mathrm{Pb}$. In contrast, similar concentrations of $\mathrm{Hg}$ and As were found in the liver and muscle tissue. According to the EWI estimates, the heavy metals in these cultured fish do not represent a risk for human consumption.
\end{abstract}

Keywords: heavy metals; bioaccumulation; Lake Chapala; carp; catfish; PTWI

\section{Introduction}

Lake Chapala is the largest freshwater lake in Mexico, with a total surface area of 114,659 ha [1]. A shallow, alkaline body of water, it has a mean depth of less than $7 \mathrm{~m}$. Lake Chapala belongs to the Lerma-Chapala Basin. Its main tributary input comes from the Lerma River, which supplies about $80 \%$ of its waters (Figure 1 ). This river is also the main source of anthropogenic pollution, including heavy metals, because 3500 industries pour their treated wastewaters into it $[2,3]$. Sediments from Lake Chapala are rich in heavy metals, and previous studies have shown that lead $(\mathrm{Pb})$ and cadmium $(\mathrm{Cd})$ are present in the exchangeable fraction of water, and possibly available for absorption by living organisms, including fish [4]. The sediments, however, have a metal adsorptiondesorption dynamic that is strongly influenced by $\mathrm{pH}$ and marked seasonal fluctuations in water levels, so low concentrations of metals in the water have also been reported $[5,6]$.

For humans, consuming fish is an excellent source of proteins and n-3 polyunsaturated fatty acids, but concern has arisen over the potential danger of heavy metals [7]. Human diets are a significant source of exposure to heavy metals that carry a toxicological risk because they cannot be degraded by biological processes. Due to this potential for harm, the Joint FAO/WHO Expert Committee on Food Additives (JECFA) has established a Provisional Tolerable Weekly Intake (PTWI) for metals that estimates the amount of a given contaminant that can be assimilated weekly per unit of body weight (bw) over a lifetime, without constituting an appreciable health risk [8]. 


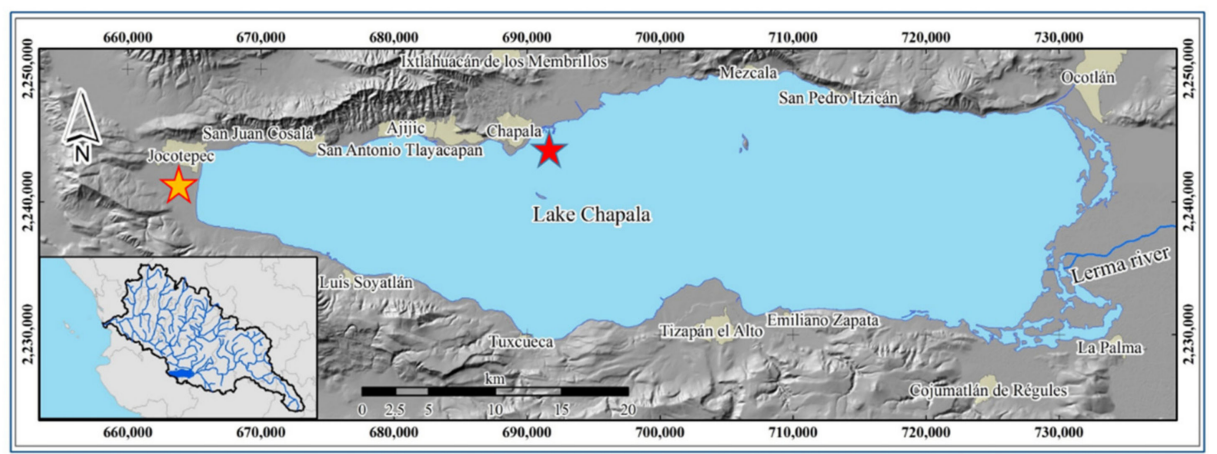

(a)

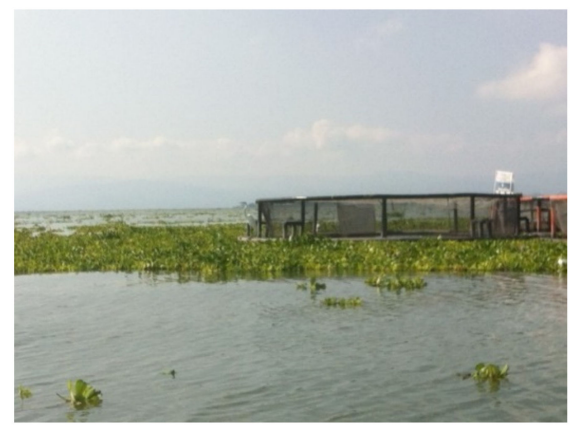

(b)

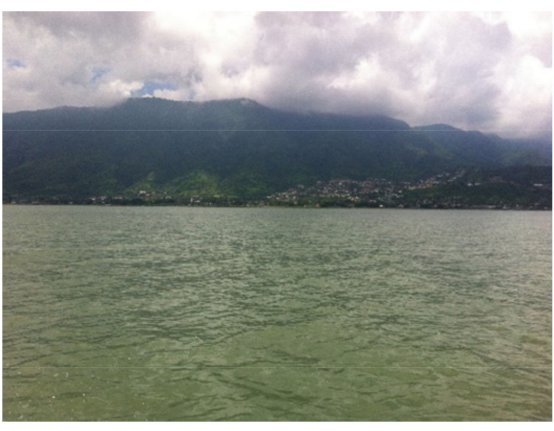

(c)

Figure 1. Location of the experimental cage in Lake Chapala. (a) Map of Lake Chapala showing with the red star the experimental cage and the yellow star the control group. (b) Experimental cage. (c) General view of Lake Chapala environment.

Contaminated fish are the principal source of heavy metals such as mercury, lead, and arsenic for humans. Previous reports in fish from Mexican water reservoirs have shown borderline-to-high quantities of heavy metals, making it essential to maintain constant monitoring of their intake through fish consumption in the diet [9-12].

The aim of the present study was to evaluate the bioaccumulation of metals $(\mathrm{Zn}, \mathrm{Cu}$, $\mathrm{Cd}, \mathrm{Hg}, \mathrm{As}, \mathrm{Pb}$ ) along time in fish cultured in a natural environment to evaluate the risk of dietary intake of metals in humans.

\section{Materials and Methods}

\subsection{Study Design and Sampling}

About one thousand catfish fingerlings (Ictalurus punctatus) aged 15 weeks (average weight $4.80 \pm 2.96 \mathrm{~g}$ and length $8.51 \pm 2.04 \mathrm{~cm}$ ), and two hundred adult carps (Cyprinus carpio) aged 30 weeks (average weight $30.04 \pm 15.55 \mathrm{~g}$, and length $11.08 \pm 4.69 \mathrm{~cm}$ ) were cultured in the same floating net cage in Lake Chapala, Jalisco, Mexico (coordinates $20^{\circ} 17^{\prime} 2.9^{\prime \prime} \mathrm{N},-103^{\circ} 10^{\prime} 27.2^{\prime \prime} \mathrm{W}$ ) (Figure 1). These fish were called the experimental group. The cage measured $6 \mathrm{~m}$ in diameter and $2 \mathrm{~m}$ deep, with a surface area of $100.13 \mathrm{~m}^{2}$ and volume of $56 \mathrm{~m}^{3}$. The mesh size was 1 inch. It was placed $3 \mathrm{~m}$ above the bottom of the lake. During the fingerling age period, the catfish were kept in a nursery cage within the larger cage, and after they remained in it for 3 months, fish were released. In order to detect any factor that might affect metal bioaccumulation, a control group of fish with the same characteristics was cultured in an earth pond in Jocotepec, Jalisco, a lakeside community (Figure 1).

The fish were fed Winfish-Zeigler $3506(3.5 \mathrm{~mm})$ until they reached a weight of $50 \mathrm{~g}$ (6 months), when this was replaced with Winfish-Ziegler 2505 (5.5 mm). Culture performance was monitored monthly in terms of biometrics, morbidity, and mortality. The properties of the lake, monitored and recorded weekly, were $\mathrm{pH}$, temperature, and dissolved oxygen. Table 1 shows the metals concentration of the feedstuffs. 
Table 1. Metal concentration of fish feedstuffs and the maximum content allowed.

\begin{tabular}{cccc}
\hline Metal & Winfish-Ziegler 3506 & Winfish-Ziegler 2505 & Maximum Content \\
[13] & (5.5 $\mathbf{~ m m ) ~}$ & $52.83 \pm 1.58$ & - \\
$\mathrm{Cu}(\mathrm{mg} / \mathrm{kg})$ & $21.77 \pm 2.45$ & $94.86 \pm 2.53$ & - \\
$\mathrm{Zn}(\mathrm{mg} / \mathrm{kg})$ & $216.50 \pm 10.89$ & $0.08 \pm 0.01$ & 1000 \\
$\mathrm{Cd}(\mu \mathrm{g} / \mathrm{kg})$ & $0.36 \pm 0.34$ & $0.43 \pm 0.02$ & 6000 \\
$\mathrm{As}(\mu \mathrm{g} / \mathrm{kg})$ & $0.90 \pm 0.28$ & $0.81 \pm 0.08$ & 5000 \\
$\mathrm{~Pb}(\mu \mathrm{g} / \mathrm{kg})$ & $1.24 \pm 0.05$ & $13.17 \pm 0.52$ & 500 \\
$\mathrm{Hg}(\mu \mathrm{g} / \mathrm{kg})$ & $17.89 \pm 3.16$ & & \\
\hline
\end{tabular}

The collection of fish samples involved taking 3-5 individuals from each species and for each experimental group at intervals of 6-7 weeks of exposure, concretely on days 0 , $38,81,123,179,241,298,369,424$, and 473 . For sampling, the fish were transferred to containers with $0.2 \mathrm{~g} / \mathrm{L}$ of MS 222 anesthetic (Sigma Aldrich). When dead, the fish were placed into new plastic bags and transported to the laboratory in a container to maintain the chain of command. The length and weight of each fish and its tissues were recorded before dissection. Liver and muscle tissue were removed, weighed, and homogenized individually, except for catfish, at the three first sampling stages where the fish were very small, and the same tissues from different fish were placed in the same bag. Samples were frozen at $-20{ }^{\circ} \mathrm{C}$ for further analysis.

\subsection{Analysis of Metals}

The concentrations of copper $(\mathrm{Cu})$, zinc $(\mathrm{Zn})$, cadmium $(\mathrm{Cd})$, lead $(\mathrm{Pb})$, mercury $(\mathrm{Hg})$, and arsenic (As) were analyzed in the liver and muscles, as well as in the fish food. The samples of fish tissues and fish food were treated by microwave digestion with nitric acid, according to the 5BI-8 sample preparation note. Briefly, $1.00 \pm 0.05 \mathrm{~g}$ of each homogenized sample was weighed in microwave vessels and $\mathrm{HNO}_{3}$ was added. The vessels were placed in a CEM Marx microwave and heated at $1200 \mathrm{~W}, 200 \mathrm{psi}$, and $210{ }^{\circ} \mathrm{C}$ for $10 \mathrm{~min}$, then allowed to cool at room temperature until the digestion time was completed. The samples were then gauged to $50 \mathrm{~mL}$ with deionized water.

All samples were analyzed in duplicate. $\mathrm{Cu}$ and $\mathrm{Zn}$ concentrations were measured by inductively coupled plasma optical emission spectroscopy (ICP-OES) in a Perkin Elmer Optima 8300DV (Shelton, CT) using internal method INS-SM/US-71, based on EPA method 6010B. For $\mathrm{Cd}, \mathrm{Pb}, \mathrm{Hg}$, and As, internal method INS-SM/US-220 was followed using inductively coupled plasma mass spectrometry (ICP-MS) in a Perkin Elmer ELAN 9000 (Shelton, CT, USA).

Standard Perkin Elmer solutions (N9300174) were used to prepare the calibration curves, which presented R2 $>0.998$. The recovery percentages performed by spiked samples of the fish ranged from $90 \%$ to $110 \%$. Precision was measured by evaluating a Perkin Elmer N9300211 solution. The coefficients of variation did not exceed 9\%. DORM-4 (fish protein) reference material from Canada's National Research Council (CNRC, Ottawa, Canada) and FAPAS T07213QC (crab meat) reference material from The Food and Environmental Research Agency (FAPAS, Sand Hutton, UK) were digested and analyzed in triplicate for quality control. Table 2 shows the recoveries of heavy metals and the corresponding certified values for the reference materials, according to the method used. 
Table 2. Certified concentration and measured values for reference material DORM-4 and FAPAS T07213QC by method.

\begin{tabular}{|c|c|c|c|c|c|c|}
\hline Element & $\begin{array}{c}\text { Reference } \\
\text { Material }\end{array}$ & Certified Conc. & Units & $\begin{array}{c}\text { Measured } \\
\text { Concentration }\end{array}$ & $\begin{array}{l}\text { Detection } \\
\text { Limit }\end{array}$ & Method \\
\hline $\mathrm{Hg}$ & DORM-4 & 410 & $\mu \mathrm{g} / \mathrm{kg}$ & 385 & 1.9 & ICP-MS \\
\hline $\mathrm{Hg}$ & $\begin{array}{c}\text { FAPAS } \\
\text { T07213QC }\end{array}$ & 93.5 & $\mu \mathrm{g} / \mathrm{kg}$ & 76.7 & 1.9 & ICP-MS \\
\hline $\mathrm{Cu}$ & DORM-4 & 15.9 & $\mathrm{mg} / \mathrm{kg}$ & 14.8 & 0.32 & ICP-OES \\
\hline $\mathrm{Zn}$ & DORM-4 & 52.2 & $\mathrm{mg} / \mathrm{kg}$ & 57.37 & 1.16 & ICP-OES \\
\hline $\mathrm{Pb}$ & DORM-4 & 416 & $\mu \mathrm{g} / \mathrm{kg}$ & 423 & 0.287 & ICP-MS \\
\hline $\mathrm{Pb}$ & $\begin{array}{c}\text { FAPAS } \\
\text { T07213QC }\end{array}$ & 50.1 & $\mu \mathrm{g} / \mathrm{kg}$ & 47.0 & 0.287 & ICP-MS \\
\hline $\mathrm{Cd}$ & DORM-4 & 306 & $\mu \mathrm{g} / \mathrm{kg}$ & 301 & 1.3 & ICP-MS \\
\hline $\mathrm{Cd}$ & $\begin{array}{c}\text { FAPAS } \\
\text { T07213QC }\end{array}$ & 5.53 & $\mu \mathrm{g} / \mathrm{kg}$ & 5.78 & 1.3 & ICP-MS \\
\hline As & DORM-4 & 6800 & $\mu \mathrm{g} / \mathrm{kg}$ & 7158 & 1.8 & ICP-MS \\
\hline As & $\begin{array}{c}\text { FAPAS } \\
\text { T07213QC }\end{array}$ & 13.9 & $\mu \mathrm{g} / \mathrm{kg}$ & 14.0 & 1.8 & ICP-MS \\
\hline
\end{tabular}

\subsection{Estimated Weekly Intake}

The estimated weekly intake (EWI) of essential $(\mathrm{Cu}, \mathrm{Zn})$ and non-essential metals $(\mathrm{Cd}, \mathrm{Pb}, \mathrm{As}, \mathrm{Hg})$ through consumption of the cultured catfish and carp were calculated, assuming a weekly consumption of $200 \mathrm{~g}$ for Latin American populations [14] and an average body weight of $70 \mathrm{~kg}$ for Mexican people [15]. Calculations were performed by applying the mean and maximum concentrations for each metal analyzed in the study in the following equation:

$$
\text { EWI }=\frac{\text { Metal Concentration } \times \text { Fish intake }(0.2 \mathbf{~ k g})}{\text { Body weight }(70 \mathbf{~ k g})}
$$

Results were compared as the percentage of contribution to their respective Provisional Tolerable Weekly Intake (PTWI) value established by JECFA [8]:

$$
\% \text { PTWI }=\frac{\text { EWI }}{\text { PTWI }} \times 100
$$

\subsection{Data Processing}

The data from the catfish and carp were stored in Excel ${ }^{\circledR}$ software. Data were ordered according to the metals $\mathrm{Hg}, \mathrm{Cu}, \mathrm{Zn}, \mathrm{Pb}, \mathrm{Cd}$, and As evaluated in the liver and muscle of the fish species.

The liver concentration factor (LCF) was obtained by dividing the mean concentration of every metal in the liver over the mean concentration of the metal in muscle, for every time in the experimental group. Diverse trendlines-linear, exponential, and logarithmic, among others-were evaluated to properly fit the catfish and carp data. The R2 coefficient and visual inspection were used as criteria to select the most appropriate function for representing the shape of the fitted data. In a second approach, the data were analyzed, and the mathematical expressions selected for the fitted data were imported into Matlab ${ }^{\circledR}$ 2015 software, which generated numerical vectors for each data category as a function of sampling time to represent the concentrations of metals that had accumulated in the organs examined. Our experimental data were then plotted versus the interpolated curves generated by the mathematical equations obtained during the fitting procedure.

\subsection{Statistical Analyses}

Means and standard deviations of every point in time by fish were then determined for every data vector, experimental versus control. F-tests run in STATGRAPHICS ${ }^{\circledR} 2018$ software were used to determine significant differences between the standard deviations of the two samples at a confidence level of $95.0 \%$. 


\section{Results}

3.1. Pattern of Metal Bioaccumulation

\subsubsection{Essential Metals: $\mathrm{Cu}$ and $\mathrm{Zn}$}

Table 3 shows the range of metal concentrations in catfish and carp obtained for every metal and the ranges of LCF for fish cultured in Lake Chapala, named the experimental group. Figures 2 and 3 show the pattern of nutritive metal bioaccumulation in muscle and liver of the cultured carp and catfish in experimental and control groups. Table 4 shows the differences between experimental and control groups, for every metal, species, and tissue. $\mathrm{Cu}$ and $\mathrm{Zn}$ did not show statistical differences between groups.

Table 3. Range of metal concentrations in muscle and liver of cultured fish, and range of liver concentration factor (LCF) by fish species in the experimental group along time.

\begin{tabular}{ccccccc}
\hline \multirow{2}{*}{ Metal } & \multicolumn{3}{c}{$\begin{array}{c}\text { Carp } \\
\text { (Cyprinus carpio) }\end{array}$} & & & \multicolumn{2}{c}{$\begin{array}{c}\text { Catfish } \\
\text { (Ictalurus punctatus) }\end{array}$} \\
\cline { 2 - 7 } & Muscle & Liver & LCF & Muscle & Liver & LCF \\
\hline $\mathrm{Cu}(\mathrm{mg} / \mathrm{kg})$ & $0.36-2.39$ & $6.44-47.81$ & $9-37$ & $0.56-3.83$ & $1.48-5.84$ & $1-9$ \\
\hline $\mathrm{Zn}(\mathrm{mg} / \mathrm{kg})$ & $8.84-16.05$ & $38.44-265.00$ & $2-28$ & $5.66-12.64$ & $17.39-28.79$ & $2-4$ \\
\hline $\mathrm{Cd}(\mu \mathrm{g} / \mathrm{kg})$ & $<1.3-3.67$ & $13.25-472.40$ & $8-220$ & $<1.3-2.14$ & $5.39-51.56$ & $1-42$ \\
\hline $\mathrm{Pb}(\mu \mathrm{g} / \mathrm{kg})$ & $3.25-17.44$ & $9.70-76.38$ & $0.6-23$ & $3.51-15.23$ & $2.87-23.90$ & $0.5-3$ \\
\hline $\mathrm{As}(\mu \mathrm{g} / \mathrm{kg})$ & $43.73-192.78$ & $38.35-126.08$ & $0.3-3$ & $10.57-126.40$ & $11.47-87.34$ & $0.3-3$ \\
\hline $\mathrm{Hg}(\mu \mathrm{g} / \mathrm{kg})$ & $<1.9-5.88$ & $<1.9-18.59$ & $0.3-5$ & $<1.9-34.56$ & $<1.9-24.60$ & $0.5-1$ \\
\hline
\end{tabular}
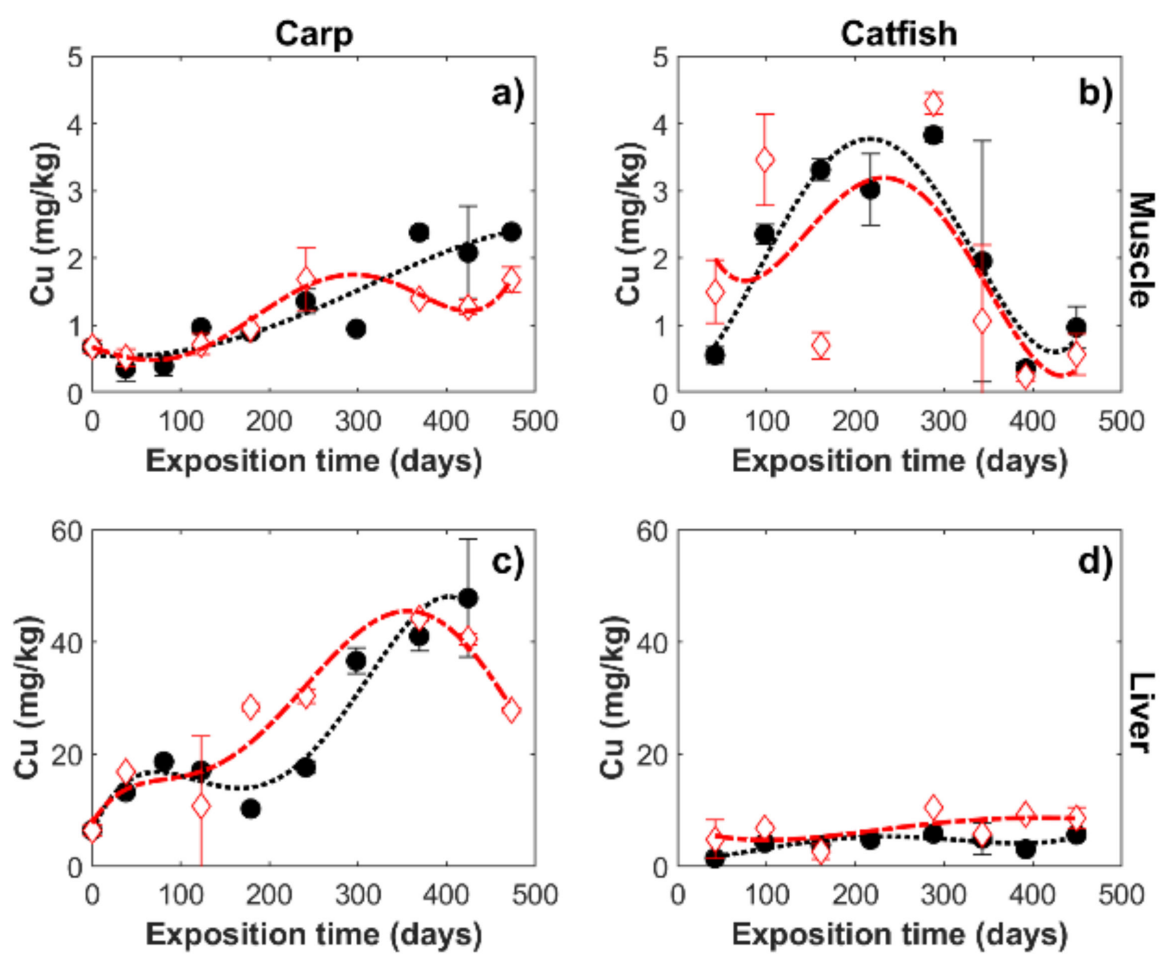

Figure 2. $\mathrm{Cu}$ accumulation in the experimental $(\bullet)$ and control groups $(\diamond)$, in front of $(\mathbf{a})$ muscle in carp, (b) muscle in catfish, (c) liver in carp, and (d) liver in catfish. 

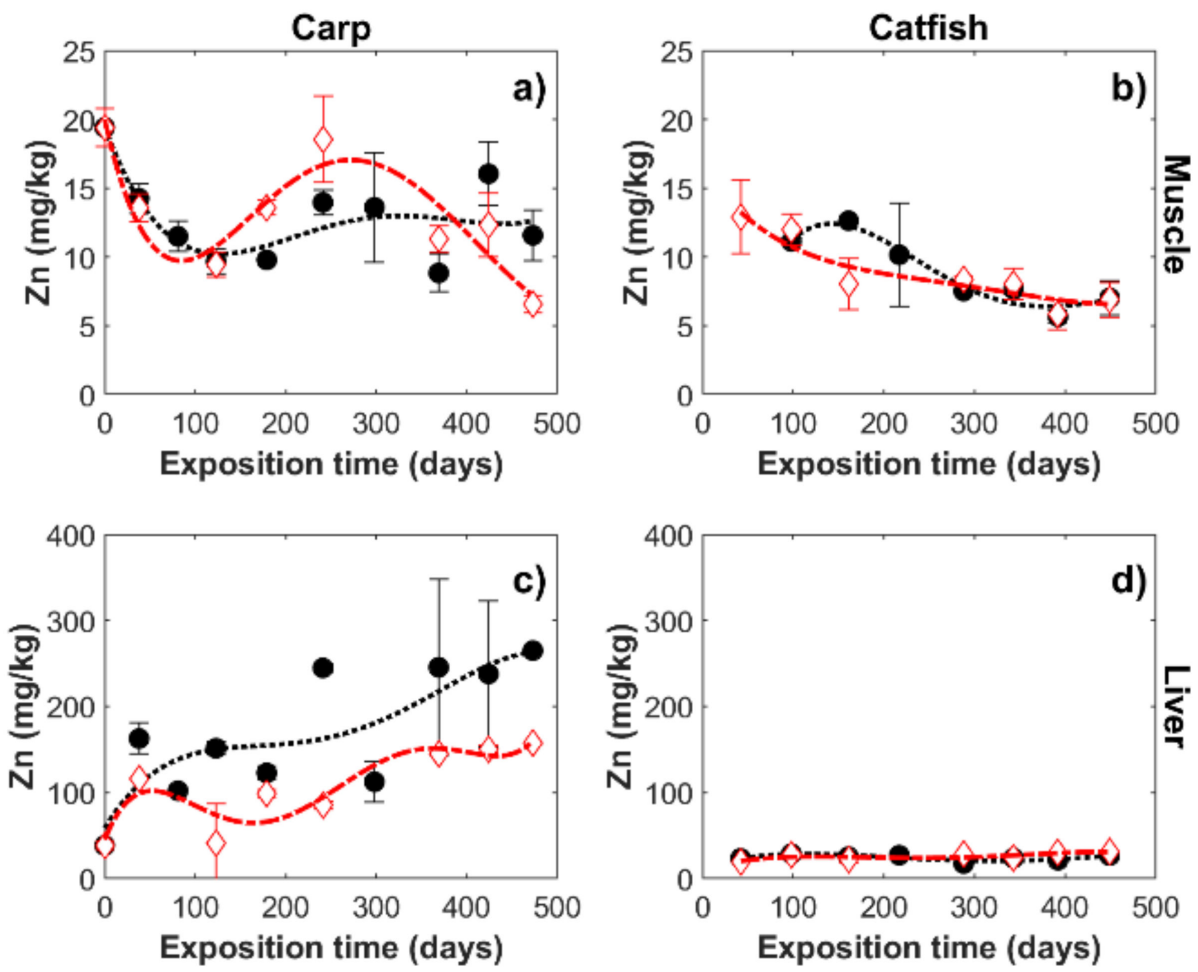

Figure 3. Zn accumulation in the experimental $(\bullet)$ and control groups $(\diamond)$, in front of $(\mathbf{a})$ muscle in carp, (b) muscle in catfish, (c) liver in carp, and (d) liver in catfish.

Table 4. F-test to compare the variances of the experimental and control groups for carp and catfish, in muscle and liver.

\begin{tabular}{cccccc}
\hline \multirow{2}{*}{ Metal } & \multirow{2}{*}{ Fish } & \multicolumn{2}{c}{ Muscle } & \multicolumn{2}{c}{ Liver } \\
\cline { 3 - 6 } & & F & $p$-Value & F & $p$-Value \\
\hline \multirow{2}{*}{$\mathrm{Cu}$} & Carp & 3.017 & 0.168 & 1.213 & 0.820 \\
\cline { 2 - 6 } & Catfish & 0.747 & 0.732 & 0.317 & 0.188 \\
\hline \multirow{2}{*}{$\mathrm{Zn}$} & Carp & 0.722 & 0.679 & 2.797 & 0.198 \\
\cline { 2 - 6 } & Catfish & 1.661 & 0.591 & 0.711 & 0.689 \\
\hline \multirow{2}{*}{$\mathrm{Cd}$} & Carp & 0.361 & 0.240 & 156.912 & $0.000 *$ \\
\cline { 2 - 6 } $\mathrm{Pb}$ & Catfish & 1.038 & 0.965 & 0.301 & 0.213 \\
\cline { 2 - 6 } & Carp & 0.582 & 0.528 & 0.368 & 0.249 \\
\hline \multirow{2}{*}{$\mathrm{As}$} & Catfish & 0.008 & $0.000 *$ & 0.605 & 0.557 \\
\cline { 2 - 6 } & Carp & 0.793 & 0.786 & 0.253 & 0.158 \\
\hline \multirow{2}{*}{$\mathrm{Hg}$} & Catfish & 2.130 & 0.380 & 1.193 & 0.851 \\
\cline { 2 - 6 } & Carp & 1.247 & 0.796 & 0.429 & 0.433 \\
\hline & Catfish & 1.112 & 0.921 & 2.240 & 0.454 \\
\hline
\end{tabular}

* Significant differences between the control and experimental group.

\section{- Copper}

Figure $2 \mathrm{a}, \mathrm{b}$ show the $\mathrm{Cu}$ accumulation patterns in the muscle of both species and in both groups. A similar concentration range was observed in the muscle of both species (Table 3), but the pattern of accumulation showed large differences, as the concentration in the carp showed a steady increase over time, while in the catfish, a curve with a maximum on day 288 was observed. This behavior in carp muscle was observed in both groups, experimental and control. 
Figure $2 \mathrm{c}, \mathrm{d}$ show the accumulation patterns of $\mathrm{Cu}$ in the fish livers. Both species showed higher concentrations in the liver, but the carp had levels 22 times higher than in the muscle tissue (Table 3), $6.44-47.81 \mathrm{mg} / \mathrm{kg}$ in liver versus $0.36-2.39 \mathrm{mg} / \mathrm{kg}$ in muscle. The catfish liver, in contrast, showed an accumulation only three times as large as that of the muscle tissue (1.48-5.84 mg/ $\mathrm{kg}$ in liver versus $0.56-3.83 \mathrm{mg} / \mathrm{kg}$ in muscle). The carp liver $(6.44-47.81 \mathrm{mg} / \mathrm{kg}$ ) also had a concentration 10 times higher than the catfish liver of the experimental group $(1.48-5.84 \mathrm{mg} / \mathrm{kg})$.

- Zinc

Figure $3 a, b$ show the $\mathrm{Zn}$ accumulation pattern in the muscles of both species. The range of concentrations for experimental groups remained in a range between 5.66 and $16.05 \mathrm{mg} / \mathrm{kg}$ for both species, and the general pattern of concentration described a descending trend. The experimental and control groups showed similar patterns of bioaccumulation.

$\mathrm{Zn}$ accumulation in the liver of both species was higher than in the muscle (Figure 3c,d) $\mathrm{Zn}$ concentrations in the liver began at similar levels in the two species, but a constant increase was seen in the carp. At the end of the experiment, the carp liver had 10 times more $\mathrm{Zn}$ than the catfish liver (265.00 versus $28.79 \mathrm{mg} / \mathrm{kg}$ ) in experimental groups.

\subsubsection{Non-Essential Metals: $\mathrm{Cd}, \mathrm{As}, \mathrm{Pb}$, and $\mathrm{Hg}$}

\section{- Cadmium}

Figure $4 \mathrm{a}, \mathrm{b}$ show the $\mathrm{Cd}$ accumulation pattern in the muscle of the catfish and carp. Muscle concentrations in both species were in the same range $(1.3-3.67 \mu \mathrm{g} / \mathrm{kg})$. The accumulation pattern in the carp showed a slight rise over time, but in the catfish, it was rather flat. Only carp showed significant differences in liver between experimental and control groups (Table 4).
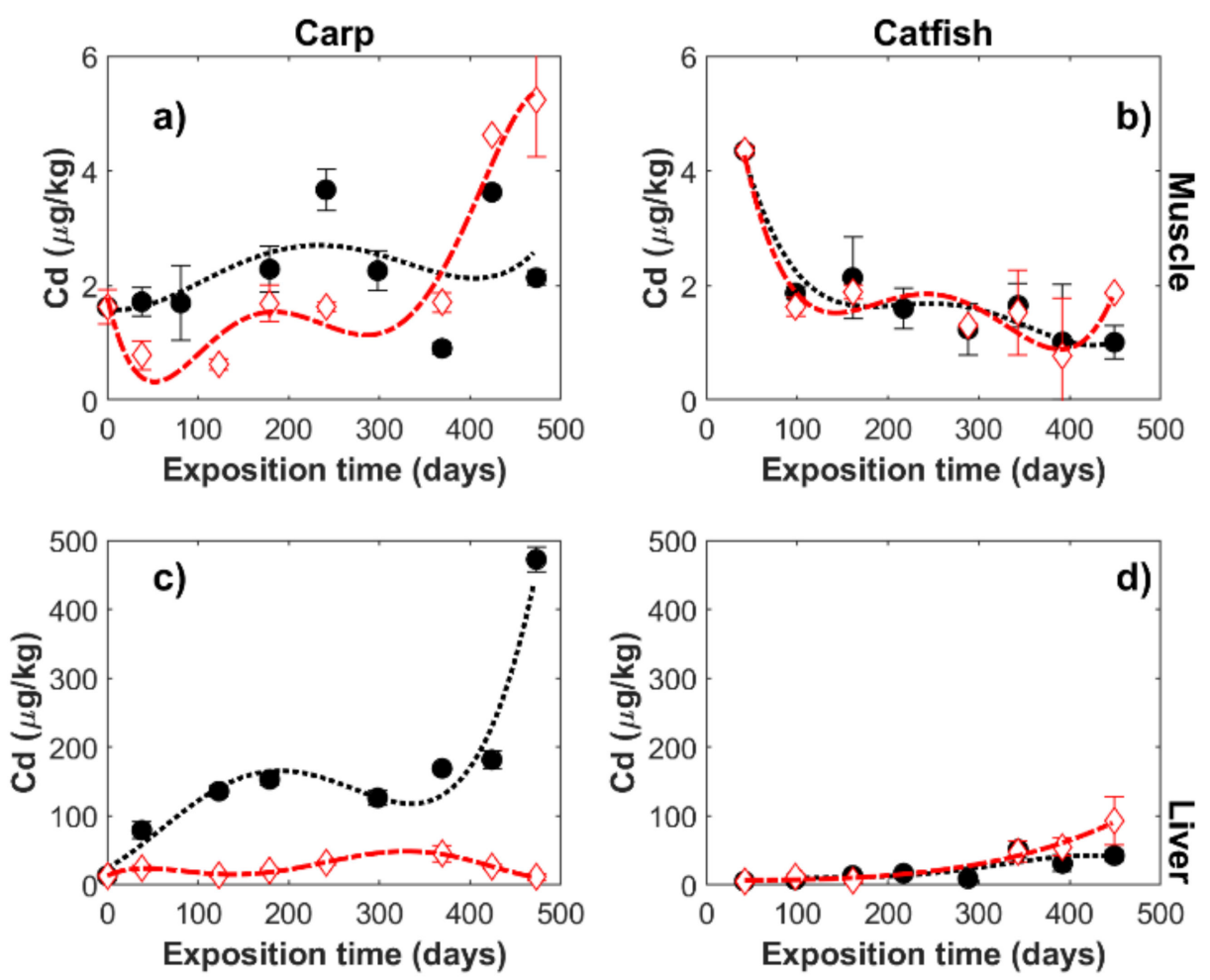

Figure 4. Cd accumulation in the experimental $(\bullet)$ and control groups $(\diamond)$, in front of (a) muscle in carp, (b) muscle in catfish, (c) liver in carp, and (d) liver in catfish.

On average, $\mathrm{Cd}$ concentrations in carp were 78 times higher in the liver than muscle and 17 times higher in the case of catfish in the experimental group, revealing the concentrating function of liver in both species (Figure $4 \mathrm{c}, \mathrm{d}$ ). The Cd concentration in the carp 
liver was twice as high as that of the catfish at the beginning of the experiment, but by the end, it was almost 10 times higher ( 472.40 versus $51.56 \mu \mathrm{g} / \mathrm{kg}$ ) for the carps cultured in Lake Chapala only. The general pattern of metal accumulation had an upward trend in the liver of the experimental fish that was more prominent in the carp. The carp cultured in Lake Chapala had a significantly high concentration in liver with respect to the carp in the earth pond.

- Lead

Figure $5 \mathrm{a}, \mathrm{b}$ show the $\mathrm{Pb}$ accumulation pattern in the muscle of the fish. The concentration ranges were very similar between both species and organs over time (Table 3). Only in the catfish muscle did the control group show a significantly higher concentration at the beginning of the experiment (Table 4).
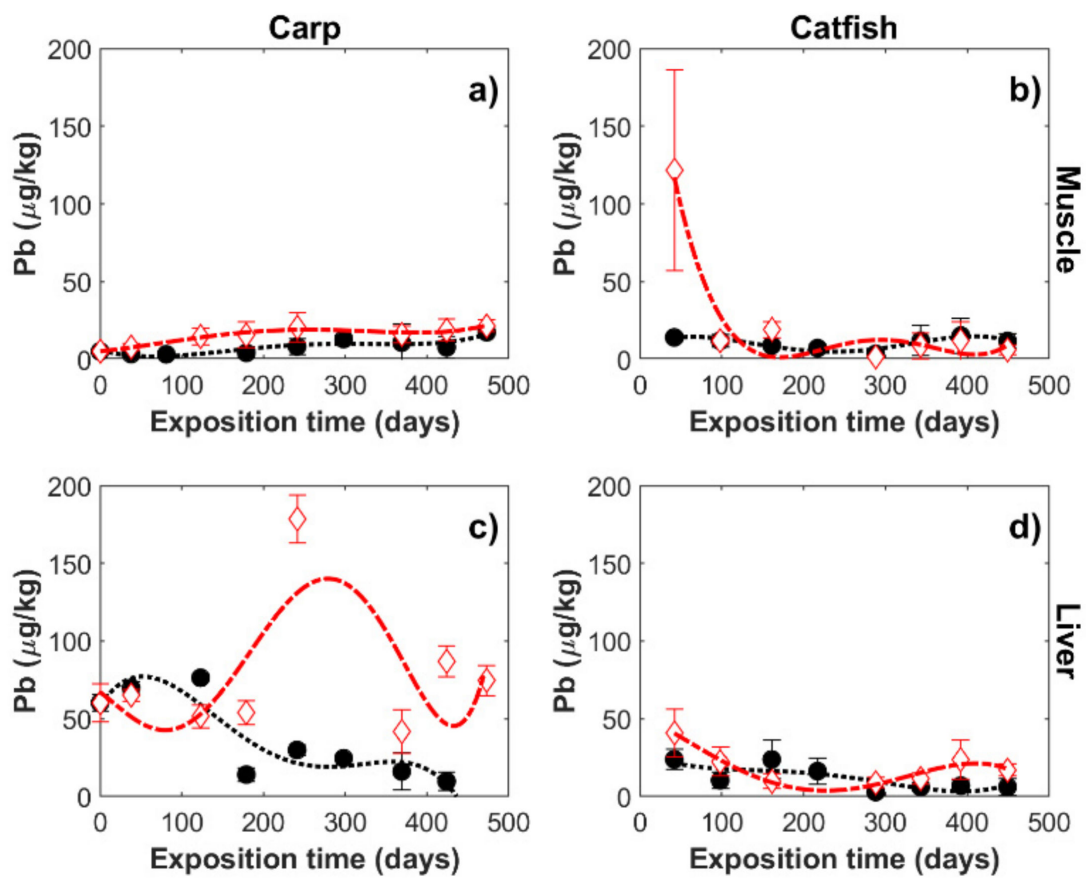

Figure 5. $\mathrm{Pb}$ accumulation in the experimental $(\bullet)$ and control groups $(\diamond)$, in front of (a) muscle in carp, (b) muscle in catfish, (c) liver in carp, and (d) liver in catfish.

In the catfish liver, the $\mathrm{Pb}$ concentrations were on average 1.2 times higher than in the muscle. LCF between 11 to 23 was observed in carp liver, which gradually decreased after day 123 (Figure 5c,d).

\section{- Arsenic}

Figure $6 \mathrm{a}, \mathrm{b}$ show the As accumulation pattern in the muscles of the catfish and carp. In this case, a downward trend of bioaccumulation was observed in the muscle of both species. Concentrations were slightly higher in the carp than the catfish, but within the same range (Table 3). As did not show statistical differences between groups (Table 4). The carps of the experimental group had on average $15 \mu \mathrm{g} / \mathrm{kg}$ of As higher than the control group, but after 298 days of exposition, they reversed the trend. No liver concentration effect was observed for As in either species, as the concentrations were slightly lower than in the muscle throughout the study period (Table 2; Figure $6 \mathrm{c}, \mathrm{d}$ ). The catfish and carp livers had ranges of $11.47-87.34$ and $38.35-126.08 \mu \mathrm{g} / \mathrm{kg}$, respectively. The general trend in the carp liver showed a soft upward shape, but the trend in the catfish was flat both in the experimental and control groups (Figure 6d). 

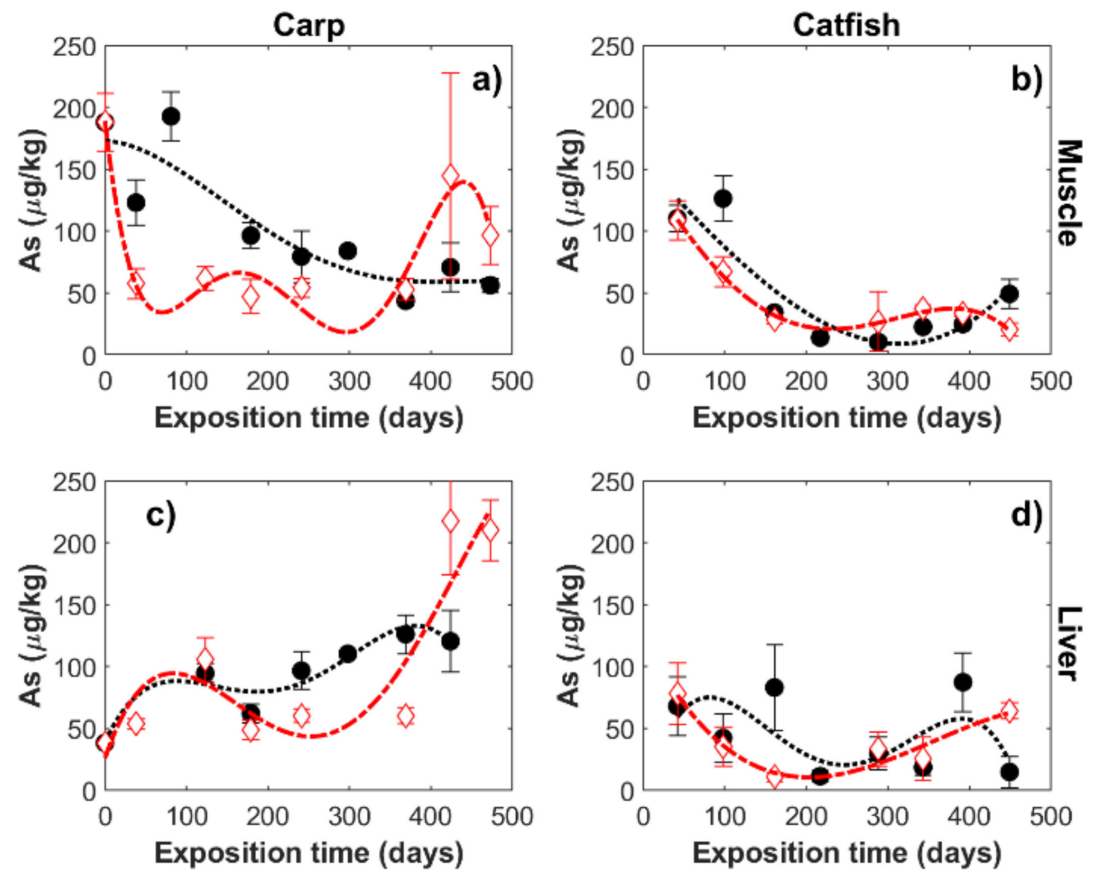

Figure 6. As accumulation in the experimental $(\bullet)$ and control groups $(\diamond)$, in front of $(\mathbf{a})$ muscle in carp, (b) muscle in catfish, (c) liver in carp, and (d) liver in catfish.

\section{- Mercury}

Figure 7 shows the $\mathrm{Hg}$ bioaccumulation in the muscle and liver of the two species. $\mathrm{Hg}$ did not show statistical differences between groups (Table 4). No liver accumulation effect was observed in catfish, and soft LCF was observed in carp (0.3 to 5). In fact, in many samples, concentrations were below the method's detection limit $(1.9 \mu \mathrm{g} / \mathrm{kg})$. Concentration ranges were similar between the tissues (Table 2), and lower in the carp $(<1.9-18.59 \mu \mathrm{g} / \mathrm{kg}$ ) than the catfish $(<1.9-34.56 \mu \mathrm{g} / \mathrm{kg})$. A slightly upward trend of bioaccumulation was observed in both species in muscle.
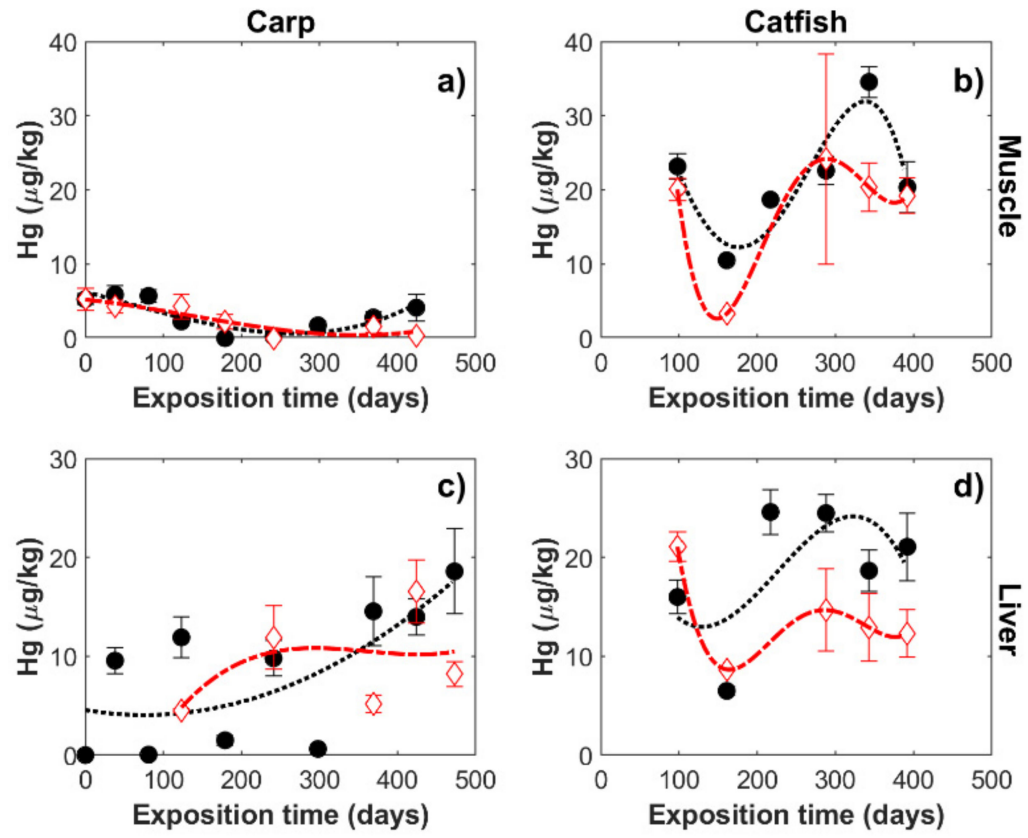

Figure 7. $\mathrm{Hg}$ accumulation in the experimental $(\bullet)$ and control groups $(\diamond)$, in front of $(\mathbf{a})$ muscle in carp, (b) muscle in catfish, (c) liver in carp, and (d) liver in catfish. 


\subsection{Estimated Weekly Intake}

The means of the metal concentrations obtained from the muscle tissue of commercialsized fish in experimental and control groups are summarized in Table 5. This information was used to calculate the EWI and the percentages of contribution to the PTWI of each metal (Table 5).

Table 5. Mean concentration (ww) of metals in fish muscle at consumption size in experimental and control groups. Estimated weekly intake (EWI) and contribution to Provisional Tolerable Weekly Intake (\%PTWI) through consumption of cultured fish.

\begin{tabular}{|c|c|c|c|c|c|c|c|c|}
\hline \multirow{2}{*}{ Metal } & \multirow{2}{*}{ Fish } & \multicolumn{3}{|c|}{ Control Group } & \multicolumn{3}{|c|}{ Experimental Group } & \multirow{2}{*}{$\begin{array}{c}\text { Reference } \\
\text { PTWI }^{+}\end{array}$} \\
\hline & & Conc. & EWI * & $\%$ PTWI & Conc. & EWI * & $\%$ PTWI & \\
\hline \multirow{2}{*}{$\begin{array}{c}\mathrm{Cu} \\
(\mathrm{mg} / \mathrm{kg})\end{array}$} & Carp & $1.45 \pm 0.21$ & 0.004 & 0.12 & $2.28 \pm 0.18$ & 0.007 & 0.19 & \multirow{2}{*}{0.5} \\
\hline & Catfish & $0.63 \pm 0.42$ & 0.002 & 0.05 & $1.09 \pm 0.80$ & 0.003 & 0.09 & \\
\hline \multirow{2}{*}{$\begin{array}{c}\mathrm{Zn} \\
(\mathrm{mg} / \mathrm{kg})\end{array}$} & Carp & $10.08 \pm 3.07$ & 0.029 & 0.41 & $12.16 \pm 3.64$ & 0.035 & 0.50 & \multirow{2}{*}{1.0} \\
\hline & Catfish & $6.93 \pm 1.11$ & 0.020 & 0.28 & $6.78 \pm 1.02$ & 0.019 & 0.28 & \\
\hline \multirow{2}{*}{$\begin{array}{c}\mathrm{Cd} \\
(\mu \mathrm{g} / \mathrm{kg})\end{array}$} & Carp & $3.86 \pm 1.88$ & 0.011 & 0.18 & $2.23 \pm 1.36$ & 0.006 & 0.11 & \multirow{2}{*}{6.0} \\
\hline & Catfish & $1.40 \pm 0.56$ & 0.004 & 0.07 & $1.23 \pm 0.37$ & 0.004 & 0.06 & \\
\hline \multirow{2}{*}{$\begin{array}{c}\mathrm{Pb} \\
(\mu \mathrm{g} / \mathrm{kg})\end{array}$} & Carp & $18.85 \pm 2.85$ & 0.054 & 0.22 & $11.97 \pm 4.98$ & 0.034 & 0.14 & \multirow{2}{*}{25} \\
\hline & Catfish & $8.97 \pm 3.02$ & 0.026 & 0.10 & $13.03 \pm 1.93$ & 0.037 & 0.15 & \\
\hline \multirow{2}{*}{$\begin{array}{c}\text { As } \\
(\mu \mathrm{g} / \mathrm{kg})\end{array}$} & Carp & $98.05 \pm 45.76$ & 0.280 & 1.87 & $57.01 \pm 13.55$ & 0.163 & 1.09 & \multirow{2}{*}{15} \\
\hline & Catfish & $30.54 \pm 8.74$ & 0.087 & 0.58 & $32.39 \pm 14.74$ & 0.093 & 0.62 & \\
\hline \multirow{2}{*}{$\begin{array}{c}\mathrm{Hg} \\
(\mu \mathrm{g} / \mathrm{kg})\end{array}$} & Carp & $0.98 \pm 0.91$ & 0.003 & 0.18 & $3.44 \pm 0.93$ & 0.010 & 0.61 & \multirow{2}{*}{1.6} \\
\hline & Catfish & $19.78 \pm 0.82$ & 0.057 & 3.53 & $27.46 \pm 10.04$ & 0.078 & 4.90 & \\
\hline
\end{tabular}

* Estimated weekly intake for a $70 \mathrm{~kg}$ person $\left(\mu \mathrm{gg} / \mathrm{kg}\right.$ bw per week). ${ }^{\dagger}$ Provisional Tolerable Weekly Intake ( $\mu \mathrm{g} / \mathrm{kg}$ bw per week) [8].

The cultured catfish and carp showed low concentrations of $\mathrm{Cu}$ and $\mathrm{Zn}$, and very low EWI values, with maximums of 0.007 and $0.068 \mu \mathrm{g} / \mathrm{kg}$ of bw respectively, as shown in Table 5.

The estimates of weekly intakes of non-essential metals in the experimental group were below the respective PTWI for both species. The contributions of $\mathrm{Cd}, \mathrm{Pb}$, and $\mathrm{As}$ represented less than $1.5 \%$ of the total PTWI, while the values for $\mathrm{Hg}$ ranged from $0.61 \%$ to $4.90 \%$ (Table 5).

\section{Discussion}

The between-tissue and between-species analyses of the metal bioaccumulation patterns showed a higher concentrating capacity of the liver for $\mathrm{Zn}, \mathrm{Cu}, \mathrm{Cd}$, and $\mathrm{Pb}$ compared to the muscle tissue. In contrast, the liver showed similar or lower concentrations of $\mathrm{Hg}$ and As than the muscle. These findings of the liver's higher capacity for concentrating $\mathrm{Zn}$, $\mathrm{Cu}$, and $\mathrm{Cd}$ agree with previous reports on the sequestrating-detoxifying function of the liver, which involves the action of the protein (Cd, Zn)-metallothionein [16-18]. The liver's high capacity for metal accumulation has been documented extensively in cyprinids for these three metals $[17,19]$ and in several families of catfish [20-23].

The comparison of the liver's accumulation capacity for $\mathrm{Cu}$ and $\mathrm{Zn}$ between the two species analyzed showed that for the carp, it was 10 times greater than that of the catfish. The findings were observed in both the experimental and the control groups, and the results disagree with previous reports, since a higher capacity in catfish liver compared to Cyprinidae species has been reported in wild fish in natural environments [24,25]. The explanation of the higher concentration obtained in the carp in our study could be attributable to two factors. Studies of fish in the same aquatic environment have reported feeding behavior and trophic position as the main sources of metals [26,27]. In our work, however, 
both species cultured in Lake Chapala were fed the same commercial food in the same cage, so they had only limited access to food from the environment. As is observed in the results section, metal concentrations in the commercial food were low, so under conditions in which the diet of the fish is controlled, their natural feeding habits and their effect on metal accumulation will not be reflected.

On the other hand, diverse studies have reported that the age of the fish correlates positively with metal accumulation [24,28]. In the present work, the age of the catfish (98-545 days) was lower than that of the carp (240-713 days). We have one moment at the same age of fish that could be comparable, at 538 days of carp (288 days of exposure) and the catfish aged 545 days ( 449 days of exposure), the $\mathrm{Zn}$ and $\mathrm{Cd}$ concentration factors (LCF) were closer. Only $\mathrm{Cu}$ maintained a large between-species difference, which was observed from the early stages of the accumulation pattern. We conclude, therefore, that at the same age, and under similar dietary and environmental conditions, the livers of the catfish and carp maintained similar concentrating capacities for $\mathrm{Zn}$ and $\mathrm{Cd}$, but not for $\mathrm{Cu}$. The catfish liver showed a different bioaccumulation pattern for $\mathrm{Cu}$ than the carp, with the latter generating an accumulation factor lower than the former.

The $\mathrm{Cd}$ pattern of accumulation in liver showed a clear difference between experimental and control groups only in the carp case, as is observed in Figure 4c. The Cd concentration at the end of the exposition time was $472.40 \mu \mathrm{g} / \mathrm{kg}$ in the experimental group versus only $23.42 \mu \mathrm{g} / \mathrm{kg}$ for the control. The effect is attributable to the lake, although the $\mathrm{Cd}$ concentration in water was acceptable $(0.01 \pm 0.00 \mu \mathrm{g} / \mathrm{L})[6]$. The $\mathrm{Cd}$ concentration in liver was far from toxic limits according to previous studies in sub-lethal exposition, where the liver Cd concentrations were between 39,300.00 and 46,100.00 $\mu \mathrm{g} / \mathrm{L}[16,17]$. However, it is advisable to continue monitoring the fish in the lake to determine the maximum level reached by $\mathrm{Cd}$ in the liver. The concentrations of $\mathrm{As}, \mathrm{Hg}$, and $\mathrm{Pb}$ found in the tissues analyzed in this study tended to be lower than those reported previously for the same fish species in the wild $[9,12,24,25,29]$. With respect to aquaculture fish, our literature review only identified reports on carp species. The concentrations of $\mathrm{As}$ and $\mathrm{Pb}$ found in the muscle in those studies $[30,31]$ were similar to our results. In another finding, the $\mathrm{Hg}$ concentrations in the muscle of carp in the present study were 400-fold less than those reported in [31]. The difference could be attributed to the fact that that work was conducted in wild carp, with free contact with sediments and contaminated sources of food. Therefore, maintaining control of the feed administered reduced the possibility of the fish accumulating heavy metals.

The liver from both species showed a 1.5-4-fold capacity for accumulating $\mathrm{Pb}$ compared to the muscle, capacities much lower than those of $\mathrm{Cu}, \mathrm{Zn}$, and $\mathrm{Cd}$ (Table 2). The concentrations of As and $\mathrm{Hg}$, however, were either similar or lower in the liver than in the muscle in both species. Here, our results are consistent with the patterns of $\mathrm{Pb}, \mathrm{As}$, and $\mathrm{Hg}$ accumulation cited in previous studies of catfish [22-24], and carp tissues [24,25,30].

The main uptake pathway for $\mathrm{Pb}$ is through the water [25]. Thus, the concentration of $\mathrm{Pb}$ in the water is decisive for bioaccumulation in fish. The $\mathrm{Pb}$ concentrations in the water samples taken from Lake Chapala during the experiment $(0.33-0.37 \mu \mathrm{g} / \mathrm{L})[6]$ were below Mexican standards $(10.00 \mu \mathrm{g} / \mathrm{L})$ [32]. This could account for the low Pb concentrations found in the tissues of both species.

Studies of the mechanism of As and $\mathrm{Hg}$ accumulation in fish have been conducted at different trophic levels. The form of the chemical is another key factor in fish metal uptake. $\mathrm{V}$ (arsenate) and methylmercury ( $\mathrm{MeHg}$ ), respectively, are the bioavailable forms of As and $\mathrm{Hg}[33,34]$. Food is the main pathway of metal intake by fish, but while the biomagnification phenomenon has been observed for $\mathrm{Hg}$ through the tropic chain with higher concentrations in predator species, As has not been associated with trophic position $[33,35,36]$. The heavy metals in the fish commercial food were always lower than international standards [13]. This explains the low As and $\mathrm{Hg}$ concentrations found in the fish in our study, since food was provided as in standard aquaculture systems with limited access to natural food sources. 
Another factor that plays a role in the uptake of metals in aquatic organisms is $\mathrm{pH}$. Lake Chapala maintained a $\mathrm{pH}$ of 8.6-9.5 during our experiment [6]. This alkaline $\mathrm{pH}$ promotes the aggregation of metals into particles that settle, thus reducing their dissolution in the liquid phase [5]. This explains the low metal concentration found in the water of Lake Chapala despite the high concentration of its sediments [6].

The data in Table 5 indicate the EWI levels for the fish from Lake Chapala in the experimental and control groups, and all of them were below $1 \%$ of the PTWI. Regarding the intake of $\mathrm{Cu}$ and $\mathrm{Zn}$ by fish consumption as essential metals, the values obtained are part of normal human dietary requirements.

The risk of consuming fish revolves around their content of non-essential heavy metals. Table 6 presents the comparison of the EWI and \% PTWI estimated during the present study from the fish cultivated in Lake Chapala, with other reports of cultured and wild freshwater fish.

Table 6 shows that the EWI and \% PTWI values for Cd in the present work were similar $(0.11 \%)$, although lower than the unique report of cultured carp $(0.35 \%)$ [30], as well as others reports of wild fish from lakes [30,37]. On the other hand, some previous works showed EWI up to two orders of magnitude higher than our work (0.395 and 0.743), and PTWI higher than 5\%, which is indicative of caution [12,38].

The EWI values for lead in the present work were one or two orders of magnitude lower than previous reports, as shown in Table 5. Nevarez et al. [12] showed the highest EWI values for lead in native catfish $(7.307 \mu \mathrm{g} / \mathrm{kg}$ of bw) living in a dam environment. According to the authors, the causes were a natural, local source of $\mathrm{Pb}$, runoff from rain, and residue from extractive mining. It is interesting to notice that Nevarez et al. [12] and Alipour and Banagar [38] reported the highest \% PTWI in two metals, $\mathrm{Cd}$ and $\mathrm{Pb}$.

The EWI for As obtained in the present work for carp $(0.163 \mu \mathrm{g} / \mathrm{kg}$ of bw) was lower, although it resulted in the same range as those reported by Alam et al. [30] for native and cultured carp $(0.271$ and $0.511 \mu \mathrm{g} / \mathrm{kg}$ of bw, respectively). The water concentrations during experiments were slightly higher in Lake Chapala (9.22-11.0 $\mu \mathrm{g} / \mathrm{L})$ [6] compared to the values reported by Alam et al. [39] (0.72 to $3.1 \mu \mathrm{g} / \mathrm{L})$. Regarding EWI for catfish, the obtained $0.093 \mu \mathrm{g} / \mathrm{kg}$ of bw agrees with Nevarez et al. [9], who reported $0.189 \mu \mathrm{g} / \mathrm{kg}$ of bw in the same type of fish. The As water concentration reported by Nevarez et al. [9] $(1.34-5.65 \mu \mathrm{g} / \mathrm{L})$ was in a similar range as that in the present study. The \% PTWI was less than $5 \%$ in the previous reports and agrees with their water and fish As concentration.

Mercury is the principal toxic metal of concern in terms of consuming fish and seafood, which constitute the primary sources of this metal [40]. In the present study, $\mathrm{Hg}$ had $0.61 \%$ and $4.9 \%$ of the PTWI in carp and catfish, respectively. Based on the mean mercury concentrations reported by Trasande et al. [41], Stong et al. [10], and Torres et al. [11] for native carp from Lake Chapala, a decrease in the concentration is noted over time that results in a lower weekly intake from native fish that represented a contribution to the PTWI of $155.36 \%$ in 2010 and $40.89 \%$ in 2014. Clearly, these figures are much higher than the results of our study, emphasizing the decrease in metal accumulation that is evident in fish cultured in floating cages. In another study, Nevarez et al. [12] reported an EWI of a dam catfish $(0.124 \mu \mathrm{g} / \mathrm{kg}$ of bw), while Łuczyńska and Paszczyk [42] reported a figure of $0.467 \mu \mathrm{g} / \mathrm{kg}$ of bw for native lake roach from the family Cyprinidae, representing contributions to the PTWI of $9.49 \%$ and $26 \%$, respectively.

Based on the estimated weekly intake values obtained in the present study, the consumption of cultured carp or catfish do not represent health risks for the entire population, even with a weekly intake above $200 \mathrm{~g}$ (or up to $1 \mathrm{~kg}$ ), due to the low bioaccumulation of metals in fish that are cultured in cages and fed commercial feed. Under these conditions, the fish present a contribution to $\mathrm{PTWI}<1.5 \%$ for $\mathrm{Cd}$, $\mathrm{As}$, and $\mathrm{Pb}$. Since $\mathrm{Hg}$ represents a greater health risk, and the main source of intake of this harmful metal is fish and shellfish consumption, the EWI values calculated also reflect a low risk (\% PTWI $<10.0)$, not only for the general population, but even more so for children and pregnant woman. Consumption of native fish, in contrast, represents a moderate-to-high risk (40.89-155.36\%). As a precau- 
tion, in populations with higher weekly intakes, consumption of free fish by children and pregnant women should be monitored and limited.

According to the results obtained, consuming fish raised under conditions of aquaculture in Lake Chapala does not represent a health risk for heavy metal consumption. The key to keeping fish under acceptable levels of metal concentrations was to provide metal-free supplementary feed. It is, however, advisable to monitor metal concentrations in wild fish as a means of control.

Table 6. Mean concentration ( $\mu \mathrm{g} / \mathrm{kg} w \mathrm{w})$, estimated weekly intake ( $\mu \mathrm{g} / \mathrm{kg}$ bw/week), and contribution to PTWI from native or cultured freshwater fish reported in previous works, compared with the present study.

\begin{tabular}{|c|c|c|c|c|c|c|c|}
\hline Metal & Fish & Origin & Country & Mean & EWI * & $\%$ PTWI & Reference \\
\hline \multirow{9}{*}{$\mathrm{Cd}$} & Carp & \multirow{2}{*}{ Lake Chapala } & \multirow{3}{*}{ Mexico } & 2.23 & 0.006 & 0.11 & \multirow{2}{*}{ Present Study } \\
\hline & Catfish & & & 1.23 & 0.004 & 0.06 & \\
\hline & Catfish & El Rejon Dam & & 148.00 & 0.395 & 6.58 & [12] \\
\hline & Cultured Carp & \multirow{2}{*}{$\begin{array}{c}\text { Lake } \\
\text { Kasumigaura }\end{array}$} & \multirow{2}{*}{ Japan } & 7.40 & 0.021 & 0.35 & \multirow{2}{*}{ [30] } \\
\hline & Wild Carp & & & 9.00 & 0.026 & 0.43 & \\
\hline & Crucian carp & \multirow{2}{*}{ Honghu Lake } & \multirow{2}{*}{ China } & 8.70 & 0.028 & 0.47 & \multirow{2}{*}{ [37] } \\
\hline & Yellow Catfish & & & 5.60 & 0.018 & 0.30 & \\
\hline & Silver Carp & $\begin{array}{l}\text { Chah Nime } \\
\text { Lake }\end{array}$ & \multirow[t]{2}{*}{ Iran } & $31.20^{+}$ & 0.096 & 1.60 & [43] \\
\hline & Carp & Gorgan Bay & & 260.00 & 0.743 & 12.38 & [38] \\
\hline \multirow{7}{*}{$\mathrm{Pb}$} & Carp & \multirow{2}{*}{ Lake Chapala } & \multirow{3}{*}{ Mexico } & 11.97 & 0.034 & 0.14 & \multirow{2}{*}{ Present Study } \\
\hline & Catfish & & & 13.03 & 0.037 & 0.15 & \\
\hline & Catfish & El Rejon Dam & & 2740.00 & 7.307 & 29.23 & [12] \\
\hline & Crucian carp & \multirow{2}{*}{ Honghu Lake } & \multirow{2}{*}{ China } & 93.80 & 0.305 & 1.22 & \multirow{2}{*}{ [37] } \\
\hline & Yellow catfish & & & 124.20 & 0.403 & 1.61 & \\
\hline & Silver carp & $\begin{array}{l}\text { Chah Nime } \\
\text { Lake }\end{array}$ & \multirow{2}{*}{ Iran } & $47.84^{\dagger}$ & 0.47 & 0.59 & [43] \\
\hline & Carp & Gorgan Bay & & 430.00 & 1.229 & 4.91 & [38] \\
\hline \multirow{6}{*}{ As } & Carp & \multirow{2}{*}{ Lake Chapala } & \multirow{3}{*}{ Mexico } & 57.01 & 0.163 & 1.09 & \multirow{2}{*}{ Present Study } \\
\hline & Catfish & & & 32.39 & 0.093 & 0.62 & \\
\hline & Catfish & El Rejon Dam & & $66.00^{+}$ & 0.189 & 1.26 & [9] \\
\hline & Cultured Carp & & Jannn & 178.90 & 0.511 & 3.41 & [200 \\
\hline & Wild carp & Kasumigaura & Japan & 95.00 & 0.271 & 1.81 & {$[30]$} \\
\hline & Yellow catfish & Honghu Lake & China & 4.00 & 0.013 & 0.09 & [37] \\
\hline & Carp & & & 3.44 & 0.010 & 0.61 & Present Stuidv \\
\hline & Catfish & & & 27.46 & 0.078 & 4.90 & \\
\hline & Carp & Lake Chapala & & 870.00 & 2.486 & 155.36 & [41] \\
\hline 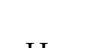 & Carp & & Mexico & 390.00 & 1.114 & 69.64 & [10] \\
\hline $\mathrm{Hg}$ & Carp & & & 229.00 & 0.654 & 40.89 & \\
\hline & Carp & $\begin{array}{l}\text { San Antonio } \\
\text { Dam }\end{array}$ & & 72.50 & 0.207 & 12.95 & [11] \\
\hline & Catfish & El Rejon Dam & & 46.50 & 0.124 & 7.75 & [12] \\
\hline & Roach & Olsztyn Lake & Poland & 140.00 & 0.467 & 29.17 & [42] \\
\hline
\end{tabular}

* Estimated weekly intake for an adult of $70 \mathrm{~kg}$ or according to author, and fish consumption of $200 \mathrm{~g} .{ }^{\dagger}$ Mean concentration adjusted to ww, 70\% humidity assumed.

\section{Conclusions}

Observations from this study indicate that metal accumulation in fish varies markedly among different tissues and metals, but not between species, with the sole exception of $\mathrm{Cu}$. Fish aquaculture in Lake Chapala is thus a viable option for producing fish with a low 
risk of heavy metal consumption by humans. Nonetheless, maintaining strict monitoring of metals in fish muscle is crucial because this lake is characterized by highly dynamic activity that causes frequent variations in volume and $\mathrm{pH}$ that affect the concentrations of metals in its waters. Finally, $\mathrm{Hg}$ in catfish showed the highest risk in terms of their PTWI, though even in this case, the \% PTWI was below $5 \%$.

Author Contributions: Conceptualization, C.A.; methodology, C.A. and E.J.H.-L.; software, E.J.H.-L.; formal analysis, X.G., D.M.C.-V., and J.M.R.; resources, C.A.; data curation, writing-original draft preparation, C.A. and D.M.C.-V. All authors have read and agreed to the published version of the manuscript.

Funding: This research was funded by Mexico's National Science and Technology Council (CONACYT), grant number 216110.

Institutional Review Board Statement: The study was conducted according to the guidelines of Mexican NOM-033-ZAG/ZOO-1994 and World Organization Aquatic Animals Health Code for slaughter of domestic animals.

Data Availability Statement: The data presented in this study are available on request from the corresponding author.

Acknowledgments: The authors acknowledge Domingo Ausin, Jesús Arriaga, and Sergio Escobar for their support in the fish culture and sampling work.

Conflicts of Interest: The authors declare no conflict of interest.

\section{References}

1. Comisión Estatal de Agua Jalisco. Available online: https://www.ceajalisco.gob.mx/contenido/chapala/ (accessed on 6 April 2021).

2. Hansen, A.M.; Zavala, A.L.; Inclan, L.B. Fuentes de contaminación y enriquecimiento de metales en sedimentos de la cuenca Lerma-Chapala. Ing. Hidraul. Mex. 1995, 10, 55-69.

3. De Anda, J.; Shear, H.; Maniak, U.; Zárate-del Valle, P.F. Solids distribution in Lake Chapala, Mexico. J. Am. Water Resour. Assoc. 2004, 40, 97-109. [CrossRef]

4. Trujillo-Cárdenas, J.L.; Saucedo-Torres, N.P.; Del Valle, P.F.Z.; Ríos-Donato, N.; Mendizábal, E.; Gómez-Salazar, S. Speciation and sources of toxic metals in sediments of Lake Chapala, Mexico. J. Mex. Chem. 2010, 54, 79-87. [CrossRef]

5. Hansen, A.M. Adsorption-desorption behaviors of $\mathrm{Pb}$ and $\mathrm{Cd}$ in Lake Chapala, Mexico. Environ. Int. 1997, 23, 553-564. [CrossRef]

6. Alvarado, C.; Ramírez, J.M.; Herrera-López, E.J.; Cortez-Valladolid, D.; Ramírez, G. Bioaccumulation of Metals in Cultured Carp (Cyprinus carpio) from Lake Chapala, Mexico. Biol. Trace Elem. Res. 2020, 195, 226-238. [CrossRef]

7. Mozaffarian, D.; Rimm, E.B. Fish Intake, Contaminants, and Human Health: Evaluating the Risks and the Benefits. JAMA 2006, 296, 1885-1899. [CrossRef]

8. World Health Organization. Evaluations of the Joint FAO/WHO Expert Committee on Food Additives (JEFCA). Available online: https:/ / apps.who.int/food-additives-contaminants-jecfa-database/search.aspx (accessed on 28 January 2021).

9. Nevárez, M.; Moreno, M.V.; Sosa, M.; Bundschuh, J. Arsenic in freshwater fish in the Chihuahua County water reservoirs (Mexico). J. Environ. Sci. Health Part A 2011, 46, 1283-1287. [CrossRef]

10. Stong, T.; Osuna, C.A.; Shear, H.; De Anda Sanchez, J.; Ramírez, G.; De Jesús Díaz Torres, J. Mercury concentrations in common carp (Cyprinus carpio) in Lake Chapala, Mexico: A lakewide survey. J. Environ. Sci. Health Part A 2013, 48, 1835-1841. [CrossRef]

11. Torres, Z.; Mora, M.A.; Taylor, R.J.; Alvarez-Bernal, D.; Buelna, H.R.; Hyodo, A. Accumulation and hazard assessment of mercury to waterbirds at Lake Chapala, Mexico. Environ. Sci. Technol. 2014, 48, 6359-6365. [CrossRef]

12. Nevárez, M.; Leal, L.O.; Moreno, M. Estimation of Seasonal Risk Caused by the Intake of Lead, Mercury, and Cadmium through Freshwater Fish Consumption from Urban Water Reservoirs in Arid Areas of Northern Mexico. Int. J. Environ. Res. 2015, 12, 1803-1816. [CrossRef]

13. Directive 2002/32/EC of the European Parliament and of the Council of 7 May 2002 on undesirable substances in animal feed. Off. J. Eur. Commun. 2006, L140, 9-10.

14. Food and Agriculture Organization of the United Nations. The State of World Fisheries and Aquaculture 2020: Sustainability in Action, 1st ed.; FAO: Rome, Italy, 2020; p. 70. [CrossRef]

15. Uribe, C.; Jiménez, A.; Morales, M.; Salazar, C.; Shamah, L. Percepción del peso corporal y de la probabilidad de desarrollar obesidad en adultos mexicanos. Salud Publ. Mex. 2018, 60, 254-262. Available online: https://scielosp.org/pdf/spm/2018.v60n3 /254-262/es (accessed on 12 March 2021). [CrossRef]

16. De Conto Cinier, C.; Petit-ramel, M.; Garin, D.; Bouvet, Y. Kinetics of cadmium accumulation and elimination in carp Cyprinus carpio tissues. Comp. Biochem. Physiol. C Toxicol. Pharmacol. 1999, 122, 345-352. [CrossRef]

17. De Smet, H.; De Wachter, B.; Lobinski, R.; Blust, R. Dynamics of (Cd, Zn) -metallothioneins in gills, liver, and kidney of common carp Cyprinus carpio during cadmium exposure. Aquat. Toxicol. 2020, 52, 269-281. [CrossRef] 
18. Kraemer, L.D.; Campbell, P.G.; Hare, L. Dynamics of Cd, Cu and Zn accumulation in organs and sub-cellular fractions in field transplanted juvenile yellow perch (Perca flavescens). Environ. Pollut. 2005, 138, 324-337. [CrossRef]

19. Calta, M.; Canpolat, O. Calta \& Canpolat. Cyprinid heavy metals. Water Environ. Res. 2006, 78, 548-551.

20. Wagner, A.; Boman, J. Biomonitoring of trace elements in muscle and liver tissue of freshwater fish. Spectrochim. Acta B 2003, 58, 2215-2226. [CrossRef]

21. Subathra, S.; Karuppasamy, R. Bioaccumulation and Depuration Pattern of Copper in Different Tissues of Mystus vittatus, Related to Various Size Groups. Arch. Environ. Contam. Toxicol. 2008, 54, 236-244. [CrossRef]

22. Jovičić, K.; Nikolić, D.M.; Jeftic, Z.V.; Đikanović, V.; Skorić, S.; Stefanović, S.M.; Lenhardt, M.; Hegediš, A.; Krpo-Ćetković, J.; Jarić, I. Mapping differential elemental accumulation in fish tissues: Assessment of metal and trace element concentrations in wels catfish (Silurus glanis) from the Danube River by ICP-MS. Environ. Sci. Pollut. Res. 2015, 22, 3820-3827. [CrossRef]

23. Arantes, F.P.; Savassi, L.A.; Santos, H.B.; Gomes, M.V.T.; Bazzoli, N. Bioaccumulation of mercury, cadmium, zinc, chromium, and lead in muscle, liver, and spleen tissues of a large commercially valuable catfish species from Brazil. An. Acad. Bras. Ciênc. 2016, 88, 137-147. [CrossRef]

24. Has-Schön, E.; Bogut, I.; Vuković, R.; Galović, D.; Bogut, A.; Horvatić, J. Distribution and age-related bioaccumulation of lead $(\mathrm{Pb})$, mercury $(\mathrm{Hg})$, cadmium $(\mathrm{Cd})$, and arsenic (As) in tissues of common carp (Cyprinus carpio) and European catfish (Sylurus glanis) from the Buško Blato reservoir (Bosnia and Herzegovina). Chemosphere 2015, 135, 289-296. [CrossRef]

25. Jia, Y.; Wang, L.; Qu, Z.; Wang, C.; Yang, Z. Effects on heavy metal accumulation in freshwater fishes: Species, tissues, and sizes. Environ. Sci. Pollut. Res. 2017, 24, 9379-9386. [CrossRef]

26. Watras, C.J.; Back, R.C.; Halvorsen, S.; Hudson, R.J.M.; Morrison, K.A.; Wente, S.P. Bioaccumulation of mercury in pelagic freshwater food webs. Sci. Total Environ. 1998, 219, 183-208. [CrossRef]

27. Clearwater, S.J.; Farag, A.M.; Meyer, J.S. Bioavailability and toxicity of dietborne copper and zinc to fish. Comp. Biochem. Physiol. C Toxicol. Pharmacol. 2002, 132, 269-313. [CrossRef]

28. Yi, Y.J.; Zhang, S.H. Heavy metal $(\mathrm{Cd}, \mathrm{Cr}, \mathrm{Cu}, \mathrm{Hg}, \mathrm{Pb}, \mathrm{Zn})$ concentrations in seven fish species in relation to fish size and location along the Yangtze River. Environ. Sci. Pollut. Res. 2002, 19, 3989-3996. [CrossRef]

29. Cui, B.; Zhang, Q.; Zhang, K.; Liu, X.; Zhang, H. Analyzing trophic transfer of heavy metals for food webs in the newly-formed wetlands of the Yellow River Delta, China. Environ. Pollut. 2011, 159, 1297-1306. [CrossRef]

30. Alam, M.G.M.; Tanaka, A.; Allinson, G.; Laurenson, L.J.B.; Stagnitti, F.; Snow, E.T. A comparison of trace element concentrations in cultured and wild carp (Cyprinus carpio) of Lake Kasumigaura, Japan. Ecotoxicol. Environ. Saf. 2002, 53, 348-354. [CrossRef]

31. Sandor, Z.; Csengeri, I.; Oncsik, M.B.; Alexis, M.N.; Zubcova, E. Trace metal levels in freshwater fish, sediment and water. Environ. Sci. Pollut. Res. 2001, 8, 265-268. [CrossRef]

32. DOF. NOM-127-SSA1-1994. Salud Ambiental. Agua Para Consume Humano. Limites Permisibles de Calidad y Tratamiento a Que Debe Someterse el Agua Para su Potabilización; Diario Oficial de la Federación: Ciudad de México, México, 2000.

33. Bowles, K.C.; Apte, S.C.; Maher, W.A.; Kawei, M.; Smith, R. Bioaccumulation and biomagnification of mercury in Lake Murray, Papua New Guinea. Can. J. Fish. Aquat. Sci. 2001, 58, 888-897. [CrossRef]

34. Ventura-Lima, J.; Fattorini, D.; Regoli, F.; Monserrat, J.M. Effects of different inorganic arsenic species in Cyprinus carpio (Cyprinidae) tissues after short-time exposure: Bioaccumulation, biotransformation and biological responses. Environ. Pollut. 2009, 157, 3479-3484. [CrossRef]

35. Mason, R.P.; Laporte, J.; Andres, S. Environmental Contamination and Toxicology Factors Controlling the Bioaccumulation of Mercury, Methylmercury, Arsenic, Selenium, and Cadmium by Freshwater Invertebrates and Fish. Arch. Environ. Contam. Toxicol. 2000, 297, 283-297. [CrossRef] [PubMed]

36. Swanson, H.K.; Johnston, T.A.; Leggett, W.C.; Bodaly, R.A.; Doucett, R.R.; Cunjak, R.A. Trophic positions and mercury bioaccumulation in rainbow smelt (Osmerus mordax) and native forage fishes in northwestern Ontario lakes. Ecosystems 2003, 6, 289-299. [CrossRef]

37. Zhang, J.; Zhu, L.; Li, F.; Liu, C.; Yang, Z.; Qiu, Z.; Xiao, M. Heavy metals and metalloid distribution in different organs and health risk assessment for edible tissues of fish captured from Honghu Lake. Oncotarget 2017, 8, 101672-101685. [CrossRef] [PubMed]

38. Alipour, H.; Banagar, G.R. Health risk assessment of selected heavy metals in some edible fishes from Gorgan Bay, Iran. Iran. J. Fish. Sci. 2018, 17, 21-34. [CrossRef]

39. Alam, M.; Tanaka, A.; Stagnitti, F.; Allinson, G.; Maekawa, T. Observations on the effects of caged carp culture on water and sediment metal concentrations in Lake Kasumigaura, Japan. Ecotoxicol. Environ. Saf. 2001, 48, 107-115. [CrossRef] [PubMed]

40. US Environmental Protection Agency (US EPA). Mercury Study Report to Congress Vol. IV: An Assessment to Exposure to Mercury in the United States; EPA 452/R-97-006; US Environmental Protection Agency: Washington, DC, USA, 1997; pp. 7.1-7.3.

41. Trasande, L.; Cortes, J.E.; Landrigan, P.J.; Abercrombie, M.I.; Bopp, R.F.; Cifuentes, E. Methylmercury exposure in a subsistence fishing community in Lake Chapala, Mexico: An ecological approach. Environ. Health 2010, 9, 1. [CrossRef] [PubMed]

42. Łuczyńska, J.; Paszczyk, B. Health risk assessment of heavy metals and lipid quality indexes in freshwater fish from lakes of Warmia and Mazury Region, Poland. Int. J. Environ. Res. Public Health 2019, 16, 3780. [CrossRef]

43. Miri, M.; Akbari, E.; Amrane, A.; Jafari, S.J.; Eslami, H.; Hoseinzadeh, E.; Zarrabi, M.; Salimi, J.; Sayyad-Arbabi, M.; Taghavi, M. Health risk assessment of heavy metal intake due to fish consumption in the Sistan region, Iran. Environ. Monit. Assess. 2017, 189, 583. [CrossRef] 